\title{
Distributions, abundances and current status of exploited populations of spanner crabs Ranina ranina off the east coast of Australia
}

\author{
Steven J. Kennelly \\ Fisheries Research Institute, New South Wales Fisheries, PO Box 21, Cronulla, New South Wales 2230, Australia
}

\begin{abstract}
A multifactorial, stratified, randomized survey was done in the spanner crab Ranina ranina fishing grounds off the coast of New South Wales, Australia, to determine fluctuations in relative distributions and abundances across a variety of spatial and temporal scales. An optimal, standardized sampling regime involving baited tangle traps (developed in previous work) was applied throughout the main geographical and depth ranges of the fishery every 2 mo for 2 yr The population exhibited a sex ratio of $55 \%$ female and marked sexual dimorphism with males generally attainng larger sizes than females. Because of a $93 \mathrm{~mm}$ minimum size limit, male crabs comprised $87.6 \%$ of the portion of the population that was targeted by fishermen and $94.4 \%$ of females were found to be protected. Further, $74.4 \%$ of the population was undersize, $69 \%$ of which were female. These results imply that the fishery should be in a sound position, ensuring long-term viability through maintenance of a large spawning population. The results generally supported this conclusion although there were large variabilities in abundances across all spatial and temporal scales investigated. A decline in the numbers of targeted, large male crabs (110 to $119 \mathrm{~mm}$ carapace length) was detected over the $2 \mathrm{yr}$ period for 2 of the 5 locations surveyed. Catches of crabs (especially females) decreased during October and December each year, coinciding with the spawning period. The distributions of crabs revealed the potential for different locations and depths as reservoirs of spawning stocks, regular suppliers of marketable crabs or relatively unproductive areas. The results are discussed in terms of current and future management strategies, potential problems due to fishing and the usefulness of stratified, randomized surveys in detecting and monitoring abundances in this fishery.
\end{abstract}

\section{INTRODUCTION}

Estimates of the abundances of exploited populations are an inherent prerequisite for the successful research and subsequert management of commercial marine fisheries. A variety of methods have been used to obtain such estimates in the study of brachyuran decapod fisheries. These include direct in situ counting of crabs using submersibles (Wenner \& Barans 1990), underwater cameras (Conan \& Maynard 1987, Tunnicliff \& Jensen 1987), or SCUBA (Ehrhardt et al. 1990), Petersen tag-recapture experiments (Melville-Smith 1988, Ehrhardt et al. 1990) and Leslie-DeLury depletion experiments (Fletcher et al. 1990). By far the most common method, however, involves estimating relative abundances via catch per unit effort data (CPUE) from surveys using standardized fishing methods. Such surveys have been used successfully for many years in a variety of fisheries and the methodologies, analysis, interpretation and value of such data are well documented (e.g. NEFC bottom trawl surveys of the northwest Atlantic: Collie \& Sissenwine 1983, Sissenwine et al. 1983, Sissenwine 1984).

For crab fisheries, the majority of CPUE-based surveys have employed standardized, demersal trawling in simple or stratified random sampling designs (e.g. Wigley et al. 1975, Botton \& Ropes 1987, Wenner \& Wenner 1988, Jones et al. 1990, Lipcius \& Van Engel 1990). Baited traps are known as an effective means for catching crabs (and therefore a good tool for sampling abundances), yet far fewer studies have used them in CPUE-based surveys (Wenner et al. 1987, Lockhardt et al. 1990). This can be ascribed to the many factors which may influence catches in traps apart from the absolute abundances of animals, and therefore compromise their usefulness as a standardized gear in surveys where constant catchabilities are required (Miller 1983, 1990). These factors include the shapes of 
traps, the materials used in their construction, trap orientation, bait, current speed, competition among traps, soak-time and the replication of traps throughout space and time. Such factors need to be examined prior to using baited traps to estimate relative abundances and consequently have been the foci of many previous studies of crab fisheries (Thomas 1953, Sinoda \& Kobayasi 1969, Miller 1978a, b, 1980, 1989, Robertson 1989; see reviews by Miller 1983, 1990). Two previous papers (Kennelly 1989, Kennelly \& Craig 1989) considered the influences of factors such as trap design, competition among traps, bait, soak-time, spatial heterogeneity and short-term temporal variability on sampling abundances of the spanner crab Ranina ranina in the fishing grounds of New South Wales (NSW), Australia. This led to the development of a standardized methodology and survey design to obtain CPUE data for this species throughout its fishing grounds.

Ranina ranina are large marine brachyuran decapods found throughout the Indo-Pacific region (Barnard 1950). They are found in coastal waters in depths of 10 to $70 \mathrm{~m}$ on sandy substrata in which they bury (Skinner \& Hill 1987). Populations of $R$. ranina have been exploited commercially in Hawaii, Japan, the Philippines, the Seychelles and, most recently, along the east coast of Australia using baited traps made of tangle-nets suspended over flat frames (Kennelly \& Craig 1989). Despite a growing literature concerning the biology and fishery of this species (Fielding \& Haley 1976, Tahil 1983, Skinner \& Hill 1986, 1987, Kennelly 1989, Kennelly \& Craig 1989, Kennelly et al. 1990), several basic aspects of its biology and ecology are unknown. In particular, and of importance to resource management, changes in the species' relative distributions and abundances throughout its fishing grounds have not been quantified. In this study, I used standardized baited traps in a multifactorial, stratified, randomized survey to estimate relative abundances of $R$ ranina across a broad spectrum of spatial and temporal scales, encompassing the main geographical range of the fishery in NSW during a 2 yr period.

\section{MATERIALS AND METHODS}

Survey design. This study was done off the north coast of NSW, Australia (Fig. 1). To obtain CPUE data, I used modifications of commercial fishing methods deployed from chartered commercial fishing vessels (6 m twin-hull boats). Traps were square frames $1.2 \times$ $1.2 \mathrm{~m}$ and made of mild steel with $85 \mathrm{~mm}$, 4-ply net doubly hung over each frame with a standard $230 \mathrm{~mm}$ fall in the net. This type of trap was found to catch the maximum number and widest size-range of Ranina

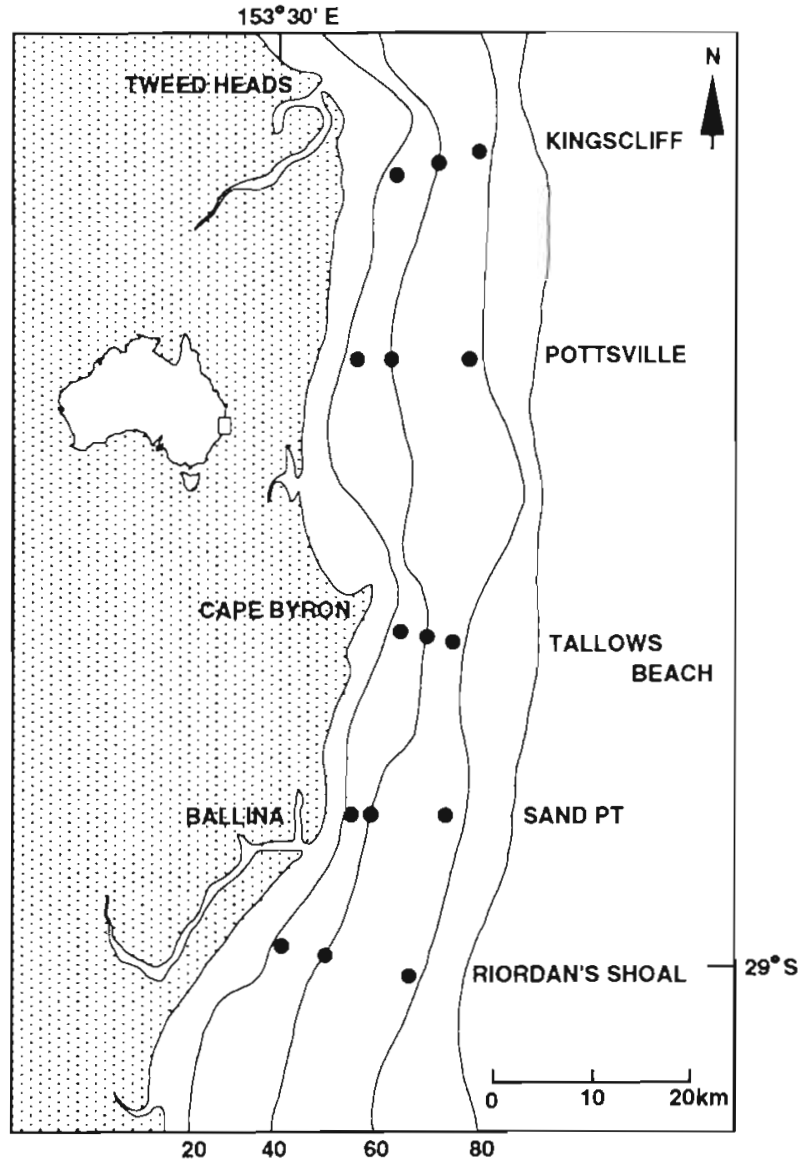

Fig. 1. Map showing the 5 locations and 3 depths which were sampled in the survey. Depth contours are in metres

ranina (Kennelly \& Craig 1989). One bait (fish skeleton) was placed in the middle of each trap (the type of fish used was found to be unimportant; Kennelly \& Craig 1989). Replicate traps were set out $60 \mathrm{~m}$ apart along trot-lines placed cross-current on the substratum in the area or depth to be sampled $(60 \mathrm{~m}$ is the distance at which neighbouring traps are known to be independent; Kennelly \& Craig 1989). These sets of traps were left for a minimum soak-time of 60 min during which all susceptible crabs in the vicinity were attracted to the bait odour and became entangled on the net (Kennelly 1989). When traps were hauled, crabs were disentangled, counted, measured (posterior edge of the eye-orbit to the posterior edge of the carapace), sexed and returned to the sea.

The survey design involved sampling 5 traps from each of 3 replicate, randomly located sets at each of 3 depths $(22,40$ and $58 \mathrm{~m})$ at 5 locations throughout the main NSW fishing grounds (total of 225 traps). Three sets of 5 traps were found to be the optimal levels of replication for a given depth and location from costbenefit analyses of a pilot survey (Kennelly 1989) which took account of (1) different variances among 


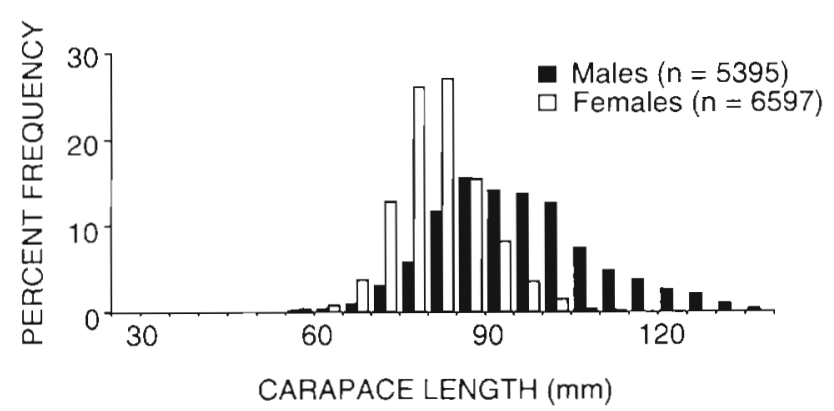

Fig. 2. Ramina ranina. Size-frequencies of all males and females caught during the survey

replicate traps and replicate sets of traps and (2) the limited time available to sample a given location and depth at sea. The 5 locations sampled were offshore from Kingscliff, Pottsville, Tallows Beach, Sand Pt and Riordan's Shoal and the depths were selected to encompass the range of depths fished by the commercial fleet (see Fig. 1). The survey was repeated every 2 mo for 2 consecutive years (1988-89).

Analysis of data. Methods similar to that outlined in Kennelly (1989) and Kennelly \& Craig (1989) were used. For each trap, I determined the total number of crabs caught, the numbers of males and females, the number of crabs that were $\geq 93 \mathrm{~mm}$ (those above the marketable size-limit) and the number of undersize crabs (<93 $\mathrm{mm})$. I also separately analysed data from each of the following size-classes: males: $\leq 79,80-89$, 90-99, 100-109, 110-119 and $\geq 120 \mathrm{~mm}$; females: $\leq 69$,
$70-79,80-89,90-99,100-109$ and $\geq 110 \mathrm{~mm}$. Each of these 17 sets of data was tested for homogeneity of variances (Cochran's test) and analysed in the relevant 5 -factor analysis variance (ANOVA) which examined all spatial and temporal scales covered during the survey. That is, $2 \mathrm{yr}$ of 6 bi-monthly periods sampled at each of 5 locations (spaced 16 to $31 \mathrm{~km}$ apart), 3 depths (from 22 to $58 \mathrm{~m}$ ), 3 sets (set 0.5 to $1 \mathrm{~km}$ apart) and 5 traps (set $60 \mathrm{~m}$ apart). Sets of data with heterogeneous variances were transformed using square roots or natural logarithms to stabilize variances and re-analysed. Student-Newman-Keuls multiple comparisons (SNK tests) were used to isolate differences among means for significant high-order interactions.

\section{RESULTS}

The sizes of Ranina ranina caught during the survey showed a marked sexual dimorphism, with males generally attaining larger sizes than females (Fig. 2). Of all crabs caught, $25.6 \%$ were legal-size $(\geq 93 \mathrm{~mm}$ carapace length), $87.6 \%$ of which were males. Further, $94.4 \%$ of females were undersize and $69 \%$ of all undersize crabs were female. The overall ratio of males to females was $1: 1.22$ which was significantly different from a $1: 1$ sex ratio $\left(\chi^{2}=120.4, \mathrm{p}<0.01\right)$.

Table 1 summarizes the ANOVAs of 6 of the more important sets of data. Most of the sets of data for individual size-classes showed similar trends and are not presented to conserve space. For all variables, there were very significant high-order interactions in the

Table 1. Summaries of analyses of variance of CPUE data gathered during the survey. To stabilize variances, the numbers of undersize crabs were transformed using $\sqrt{x+1}$. ns: non-significant $(p>0.05)$; ${ }^{\cdot}$ significant $(p<0.05)$; ${ }^{*}$ significant $(p<0.01)$. In some sets, 1 replicate trap was lost to predatory turtles. The mean of the remaining 4 replicates was substituted and the residual degrees of freedom adjusted accordingly

\begin{tabular}{|c|c|c|c|c|c|c|c|}
\hline Treatment & d.f. & $\begin{array}{l}\text { Total } \\
\text { crabs }\end{array}$ & $\begin{array}{l}\text { Male } \\
\text { crabs }\end{array}$ & $\begin{array}{c}\text { Female } \\
\text { crabs }\end{array}$ & $\begin{array}{l}\text { Legal } \\
\text { crabs }\end{array}$ & $\begin{array}{l}\text { Undersize } \\
\text { crabs }\end{array}$ & $\begin{array}{c}\text { Males } \\
110-119 \mathrm{~mm}\end{array}$ \\
\hline Year & 1 & ns & ns & ns & ns & ns & $\cdot$ \\
\hline Period & 5 & ns & ns & ns & $\cdots$ & $\cdot$ & $\cdot$ \\
\hline Location & 4 & $\cdots$ & $\cdots$ & $\cdots$ & . & 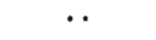 & $\cdot$ \\
\hline Depth & 2 & ns & $\cdot$ & ns & . & ns & . \\
\hline$Y \times P$ & 5 & ns & ns & ns & ns & ns & ns \\
\hline $\mathrm{Y} \times \mathrm{L}$ & 4 & $\cdots$ & $\cdots$ & $\cdots$ & $\cdot$ & $\cdots$ & ns \\
\hline $\mathrm{Y} \times \mathrm{D}$ & 2 & ns & ns & ns & ns & ns & ns \\
\hline $\mathrm{P} \times \mathrm{L}$ & 20 & $\because$ & $\cdots$ & $\cdots$ & $\cdots$ & $\cdots$ & $\cdots$ \\
\hline $\mathrm{P} \times \mathrm{D}$ & 10 & $\cdot$ & $\mathrm{ns}$ & ns & .. & $\mathrm{ns}$ & $\cdots$ \\
\hline $\mathrm{L} \times \mathrm{D}$ & 8 & $\cdots$ & $\cdots$ & $\cdots$ & ns & $\cdots$ & ns \\
\hline $\mathrm{Y} \times \mathrm{P} \times \mathrm{L}$ & 20 & .. & .. & $\cdots$ & ns & $\cdots$ & $\because$ \\
\hline$Y \times P \times D$ & 10 & $\cdots$ & $\cdots$ & $\cdots$ & $\cdots$ & . & ns \\
\hline $\mathrm{P} \times \mathrm{L} \times \mathrm{D}$ & 40 & .. & $\cdots$ & $\cdots$ & $\cdots$ & $\cdots$ & $\cdot$ \\
\hline$Y \times L \times D$ & 8 & .. & $\cdots$ & . & .. & . & $\cdots$ \\
\hline $\mathrm{Y} \times \mathrm{P} \times \mathrm{L} \times \mathrm{D}$ & 40 & $\cdots$ & $\cdots$ & $\cdots$ & $\ldots$ & . & $\cdots$ \\
\hline Set & 360 & $\cdots$ & $\ldots$ & • & $\cdots$ & . & ns \\
\hline Residual & 2119 & & & & & & \\
\hline
\end{tabular}




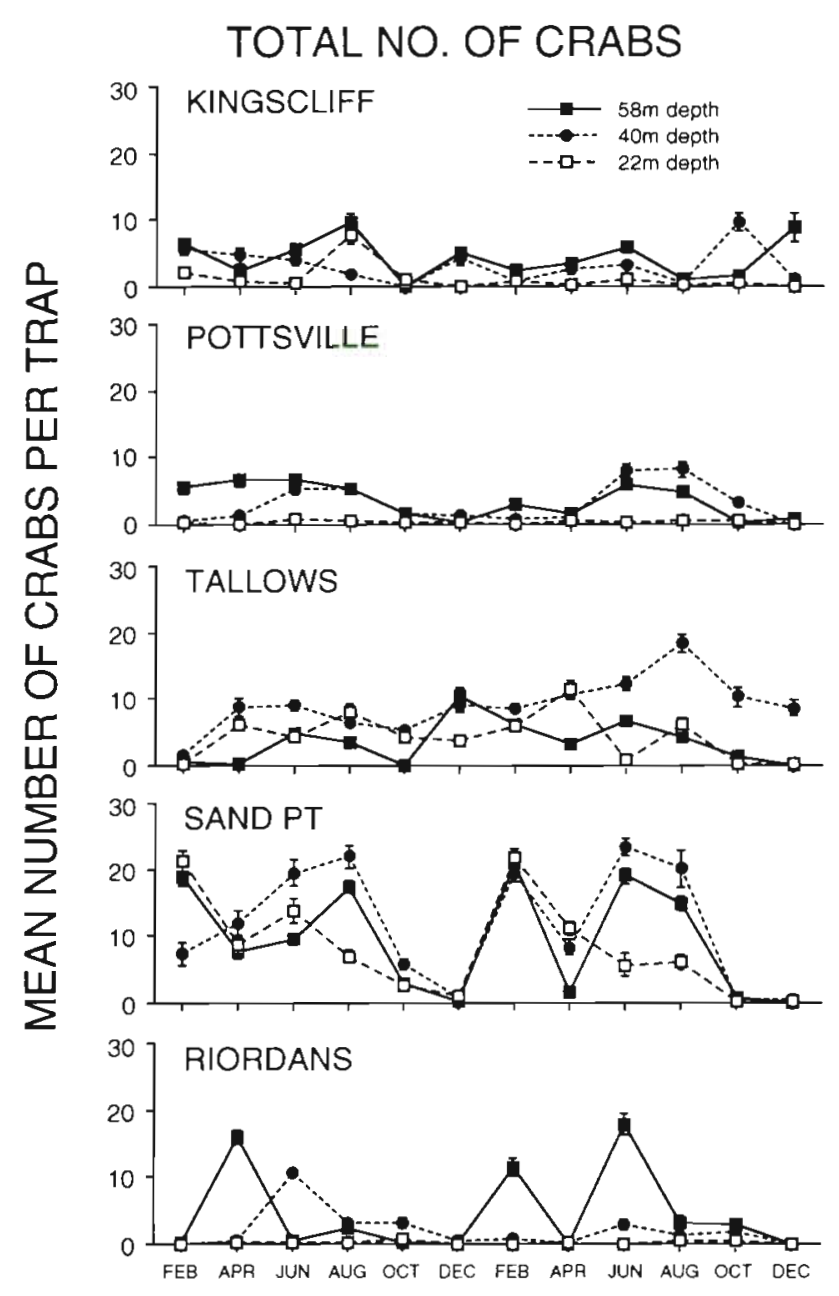

Fig. 3. Ranina ranina. Fluctuations in the mean CPUE ( $\pm \mathrm{SE})$ during the survey at each location and depth $(n=15)$

ANOVAs ( $p<0.01$; Table 1$)$ indicating that abundances of all categories of Ranina ranina vary a geat deal among years, different periods, locations and depths. This means that differences among years (the main effect which quantifies increases or decreases in abundances of this species over time) depends on the particular period, location and depth in question.

Figs. 3 to 8 are graphs of the means associated with the significant high-order interaction (Years $x$ Period $x$ Location $\times$ Depth) for the 6 major variables. Not surprisingly, SNK tests of the 180 means compared for each variable revealed no significant differences. Despite this, several trends are apparent in these figures.

Firstly, more Ranina ranina were caught off Sand Pt than any other location, with Tallows Beach recording the next largest abundances (Fig. 3). At certain times large numbers of crabs were caught in the deep site off Riordan's Shoal. In general there were smaller numbers of crabs recorded in October to December each

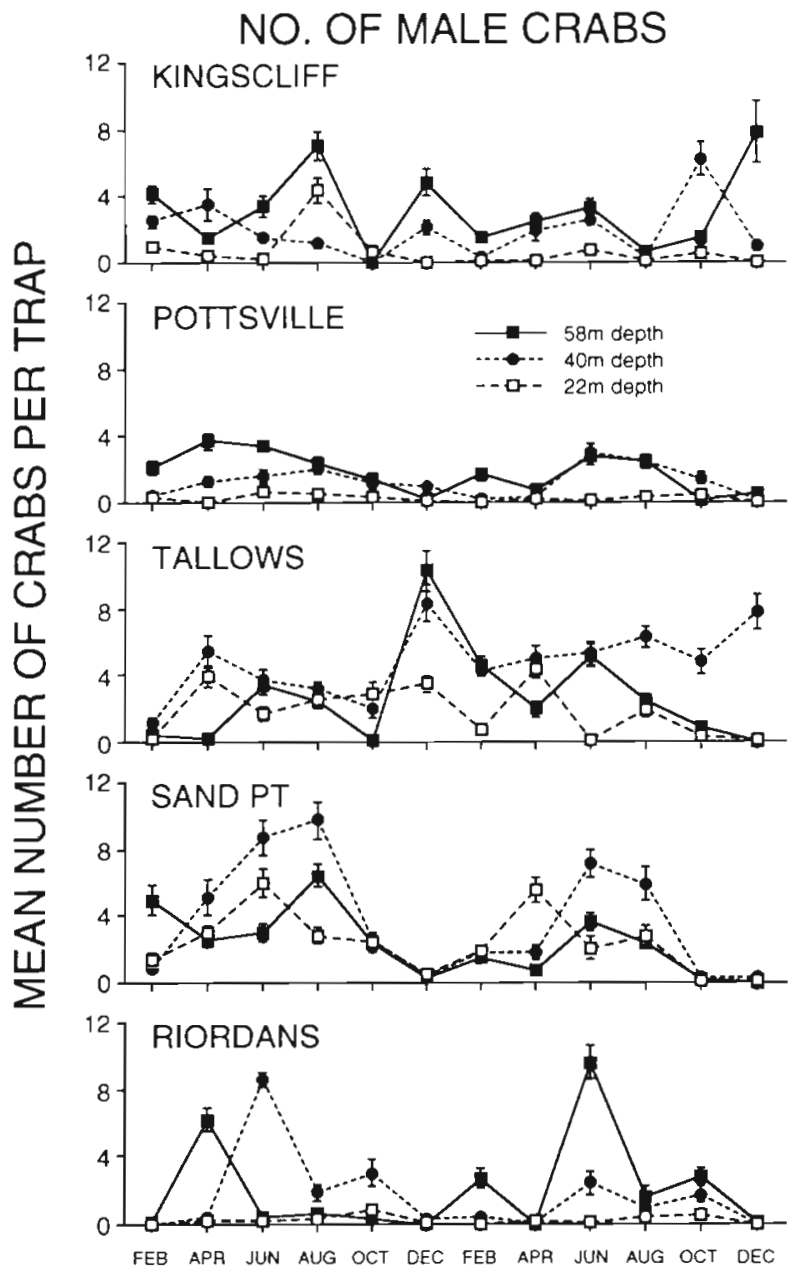

Fig. 4. Ranina ranina. Fluctuations in the mean CPUE ( $\pm \mathrm{SE}$ ) of males during the survey at each location and depth $(n=15)$

year compared to other times. There also were smaller numbers of crabs caught in the shallow depth off Kingscliff, Pottsville and Riordan's Shoal.

Fig. 4 shows that the relative abundances of male crabs were large off Sand Pt at most times except October to December each year. Relative abundances were also large in the mid-depth site off Tallows Beach at most times. There were large numbers of males recorded at certain times off Kingscliff, Pottsville and Riordan's Shoal in the deep and middle depths.

Fig. 5 shows that the relative abundances of female crabs were consistently small off Kingscliff and Pottsville. Larger numbers occurred at the deep site off Riordan's Shoal at certain times. Tallows Beach had large numbers of females in the middle depth in June to October of the second year of the survey and in the shallow depth in February and April. By far the largest numbers of female crabs occurred off Sand Pt at most times except. October to December each year. These 


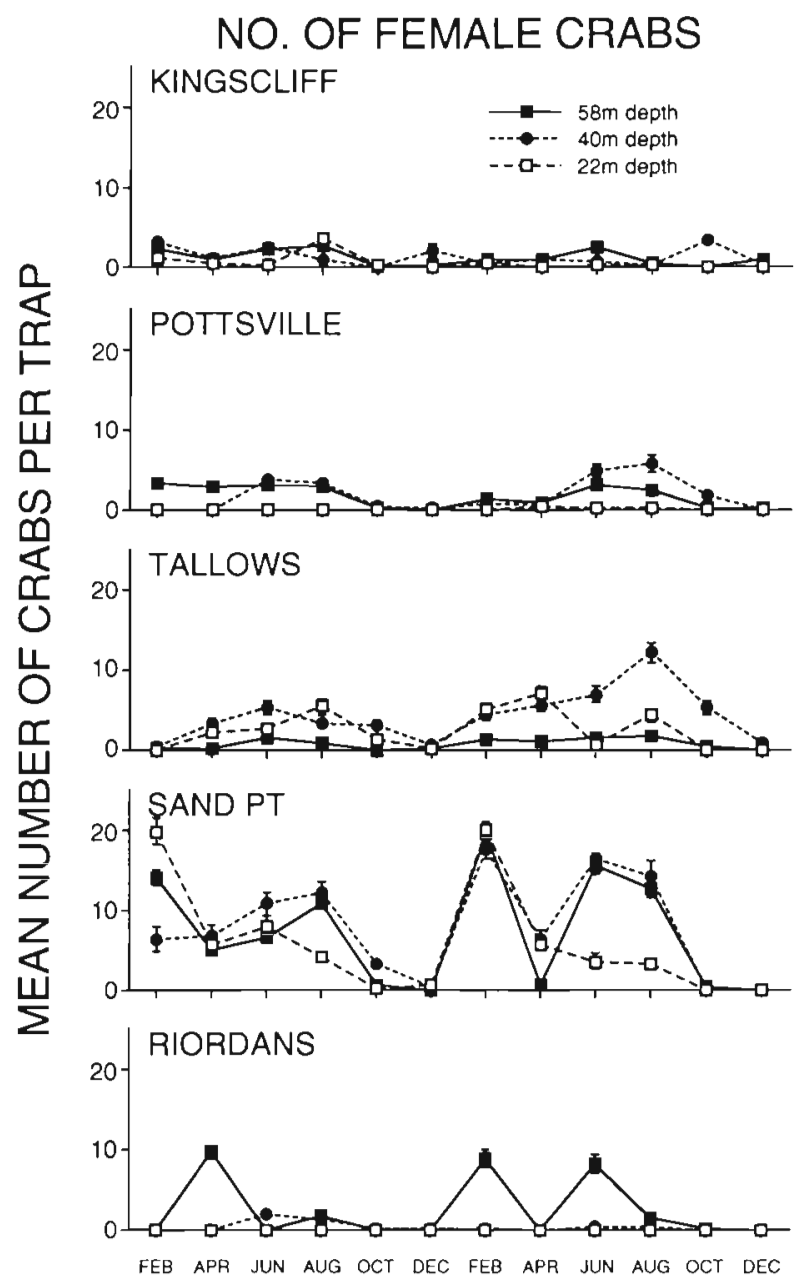

Fig. 5. Ranina ranina. Fluctuations in the mean CPUE ( \pm SE) of females during the survey at each location and depth ( $\mathrm{n}=15$ )

occurred at all depths although in the second year, fewer females were caught in the shallow depth.

Fig. 6 shows that the relative abundances of legal-sized crabs were greatest off Sand Pt in all depths at most times except October to December each year. Large catches occurred off Kingscliff, Pottsville and Riordan's Shoal in the middle and deep sites at certain times whilst few were caught in shallow depths. Abundances of legal-sized crabs off Tallows Beach were fairly evenly distributed throughout the survey and across depths. Because a large proportion of legal-sized crabs were male (see Fig. 2), many of the trends in their abundances were similar to those seen above for male crabs (Fig. 4).

Fig. 7 shows that few undersize crabs were caught off Kingscliff and Pottsville during the survey, whilst large numbers were recorded in all depths off Sand Pt during all periods except October to December each year. Large numbers were also caught off Riordan's Shoal in deep water at certain times and off Tallows Beach at all

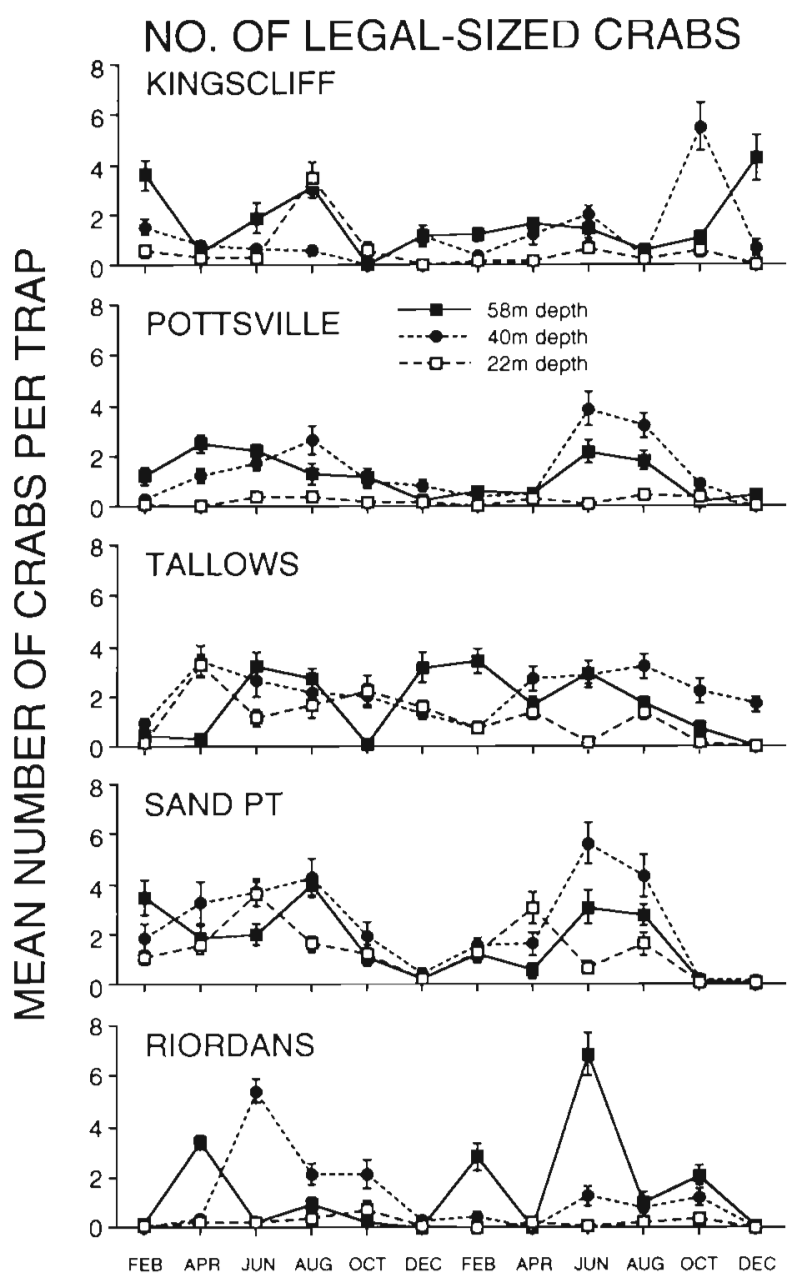

Fig. 6. Ranina ranina. Fluctuations in the mean CPUE ( $\pm \mathrm{SE}$ ) of legal-sized crabs during the survey at each location and depth $(n=15)$

times, particularly in the middle and shallow depths. Because a large proportion of undersized crabs were female (see Fig. 2), trends in their abundances were similar to those seen above for female crabs (Fig. 5).

The ANOVA for the 110-119 mm size class of males is included in Table 1 and the data are graphed in Fig. 8 because (1) this group comprised a large section of the targeted portion of the population and (2) the ANOVA for this set of data was the only one that showed a significant main effect among years. Upon examination of the means of this variable for the 2 years of the survey, this significant effect among years was found to be due to a decline in abundances (of ca $33 \%$ ) from $0.2 \pm 0.015$ (SE) crabs per trap in 1988 to $0.14 \pm 0.012$ in 1989 . However, because of the significant high-order interaction it is invalid to interpret the significance of this main effect in isolation from the possible influences of the other factors in the survey. Fig. 8 shows that the decline in abundances was not consistent at all locations, depths and periods. 


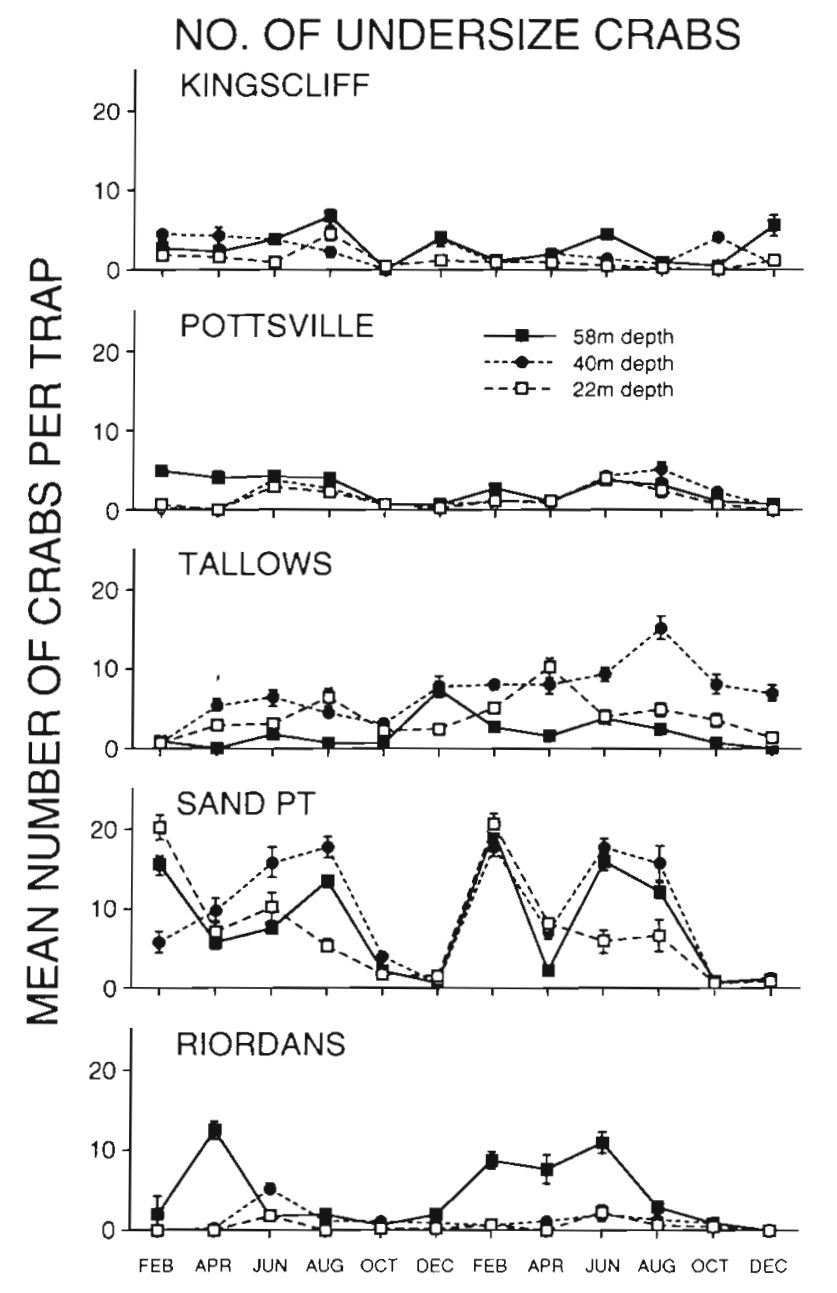

Fig. 7. Ranina ranina. Fluctuations in the mean CPUE ( $\pm \mathrm{SE}$ ) of undersize crabs during the survey at each location and depth $(\mathrm{n}=15)$

Large numbers occurred early in the survey off Kingscliff at the deep site, but decreased to small values in October to December of the first year. A similar decline occurred off Pottsville in the middle and deep sites, but increases occurred at these depths in June to August of the second year. Consistent abundances of these large crabs occurred off Tallows and Riordan's Shoal throughout the survey, the latter occurring only in the middle and deeper sites. This group of crabs showed wide fluctuations in abundances off Sand Pt, with greatest numbers occurring in the deep and mid-depths and very low numbers recorded in October to December each year.

\section{DISCUSSION}

One of the most basic aspects of any population is its sex ratio and in the present study, $55 \%$ of all Ranina ranina caught were females. By contrast, other studies

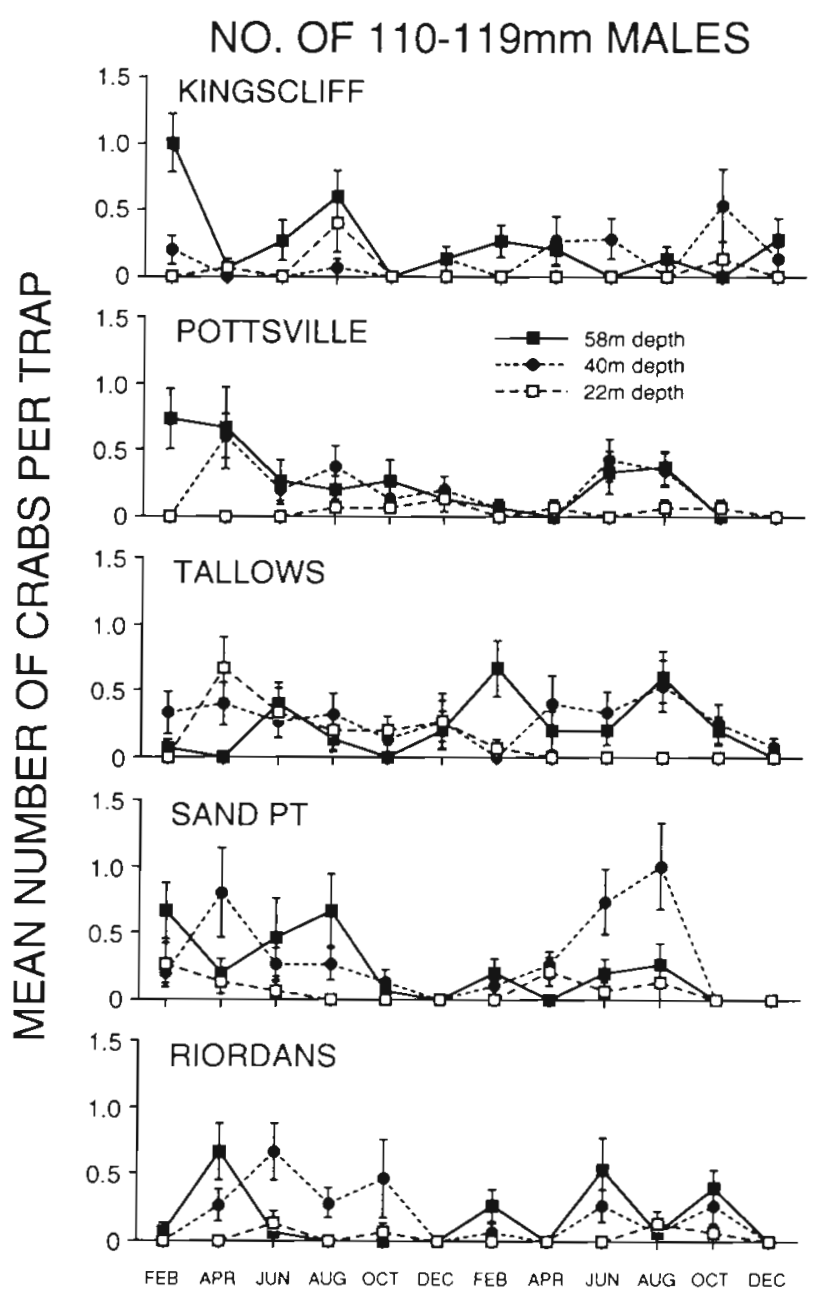

Fig. 8. Ranina ranina. Fluctuations in the mean CPUE ( $\pm \mathrm{SE}$ ) of 110-119 $\mathrm{mm}$ males during the survey at each location and depth $(\mathrm{n}=15)$

have reported this species sex ratio as dominated by males (Fielding \& Haley 1976, Brown 1986, Skinner \& Hill 1986). A number of factors may account for this difference: (1) high rates of exploitation of the larger, targeted, male crabs may have reduced their numbers (Fielding \& Haley 1976, and see below); (2) because females respond more quickly to food stimuli, they may be more catchable in baited traps (Skinner \& Hill 1987); (3) the traps used in the present study were designed to catch a wider size-range of crabs than commercial traps and traps used in previous studies (Kennelly \& Craig 1989); and/or (4) this merely may reflect a natural phenomenon as deviations from a $1: 1$ sex ratio are not unusual for marine crustaceans (Wenner 1972).

Another characteristic of populations of Ranina ranina is the species' marked sexual dimorphism with males being generally larger than females (Fig. 2; see also Fielding \& Haley 1976, Tahil 1983, Brown 1986). In the present study, male crabs comprised the majority of 
the targeted portion of the population and most females were protected by the legal minimum size limit of $93 \mathrm{~mm}$ (Fig. 2). Further, $74.4 \%$ of the available population was undersize, $69 \%$ of which was comprised of females. Given (1) the protection of these large numbers of females by the minimum size limit, (2) the sexual maturity of males at a small size (ca $60 \mathrm{~mm}$; Fielding \& Haley 1976), (3) their promiscuity in mating (Onizuka 1972, Skinner \& Hill 1987), (4) acceptance of spermatophores so that most females are impregnated during the spawning period (Brown 1986, Skinner \& Hill 1987), and (5) their high fecundity (ca 100000 to 200000 eggs per female; Fielding \& Haley 1976, Brown 1986, Kennelly unpubl.), the population of, and therefore the fishery for, $R$. ranina should be in a sound position, ensuring long-term viability through the maintenance of a large spawning population.

Most of the results from the survey discussed in this paper do not negate this conclusion for this fishery. That is, despite very large patchiness in the relative distributions and abundances of all the various sets of data, there was little evidence of any dramatic declines in abundances (except perhaps for 1 size class of males - see below). The large variabilities evident from highly significant Year $\times$ Period $\times$ Location $\times$ Depth interaction terms in all the ANOVAs indicated that, in general, the relative abundances of these crabs depend on the particular year, period, location and depth that one considers. Nevertheless, the trends detected in Figs. 3 to 8 indicated several patterns in the distributions and abundances of these populations.

Trends detected for male and female crabs (Figs. 4 \& 5) generally resembled those detected for legal-sized and undersized crabs respectively (Figs. $6 \&$ 7), simply because most legal-size crabs were male and most undersize crabs were female (discussed above). Further, because the trends detected for these groups of crabs were generally similar, their combination (as the total numbers of crabs) also reflected these patterns (Fig. 3). There were a number of patterns to emerge from these sets of data

Firstly, there was a moderate decline in the catches of males and a large decline in the catches of females in October and December each year (Figs. 3, 4 \& 5). These periods coincided with the spawning period of Ranina ranina, with females ovigerous from October to January (Tahil 1983, Brown 1986, Skinner \& Hill 1987). Perhaps during this time of the year, $R$. ranina (especially females) are less susceptible to capture, probably due to reduced feeding and/or some migratory behaviour at this time (Kennelly unpubl.). This confirms Skinner \& Hill's (1986) results of declines in commercial catches (particularly females) during the spawning period, and reduced rates of emergence of ovigerous females in aquaria at this time.
Another pattern to emerge was that more female crabs were detected off Sand Pt than off other locations (Fig. 5). This aggregation was evident at all times of the year except during the spawning period, perhaps due to a spawning migration at this time (see above; Kennelly unpubl.). In terms of the long-term management of this fishery, the existence of such an aggregation of crabs suggests (1) this location's potential as a reservoir of spawning stock and (2) the possibility that similar aggregations occur elsewhere along the coast.

Another pattern to emerge from this survey was that small numbers of both sexes were detected in shallow depths off Kingscliff, Pottsville and Riordan's Shoal (Figs. 3, $4 \& 5$ ). This would be of particular interest to the commercial fishery as it suggests that shallow areas in these places may be less productive than deeper sites. Further, the consistent appearance of male and legalsized crabs off Tallows Beach at most times highlights the potential for this location as a regular supplier of marketable crabs (Figs. $4 \& 6$ ). The fact that male crabs were present in the deep and mid-depths off Kingscliff and Tallows Beach in October to December each year (when they were found to be scarce off other locations) may be evidence that these places were the destinations of the spawning migration eluded to above.

The data from the $110-119 \mathrm{~mm}$ size class of male crabs showed an overall decrease of ca $33 \%$ between the 2 years of the survey, Because of the significant high-order interaction in the ANOVA and the trends seen in Fig. 8, I must conclude that this decline was not a general fishery-wide trend, but only occurred off Kingscliff and Pottsville in certain depths. The consistent abundances of this size class off Tallows Beach and Riordan's Shoal and the quite variable abundances off Sand Pt all suggest that there were no appreciable declines in these places. Thus, any evidence of overfishing for this targeted portion of the population over the duration of the survey can only be suggested for Kingscliff and Pottsville. It should be noted, however, that this decrease is based on only 2 yr of data and may merely be a short-term fluctuation, not a serious longterm decline (see Lipcius \& Van Engel 1990). Nevertheless, the present survey is twice as long as other surveys of brachyuran decapods using traps (Wenner et al. 1987, Lockhart et al. 1990) and provides at least the minimal replication of years.

Whilst the rationale behind a minimum size limit in this fishery is that it protects most of the population (including most of the spawning females), the data available suggest that there may be a few problems in this fishery. Firstly, the population's sex ratio of $55 \%$ females may be a result of fishermen targeting the male portion of the population. Secondly, despite significant spatial and temporal variability in abundances, the detection of some decline in the targeted part of the population 
(110-119 mm males) over the minimal 2 yr period of the survey for 2 of the 5 locations examined is not an expectation of healthy stocks in those places. Thirdly, it is known from Kennelly et al. (1990) that the tangle-net method of capture used in this fishery leads to significant mortality of discarded conspecifics (ca 60\%), which could negate most of the intended effect of the size limit

In the present paper, I found that $74.4 \%$ of the available population is undersize of which $69 \%$ are female, suggesting that handling mortality may affect (1) the availability of legal-sized crabs in the short term (the $31 \%$ of undersize crabs that are male and are caught and released), (2) the numbers of females and the fecundity of the population in the mid term, and consequently (3) the size of the exploitable stock in the long term. Whilst it is impossible to determine whether the decrease in numbers of large males detected at 2 locations during this survey is evidence of the first, short-term effect, the results recommend careful monitoring of this fishery to ensure that effects on fecundity do not develop. It should be noted that in the commercial fishery, some fishermen reduce handling mortality by using tangle nets designed to catch a maximum of large males and a minimum of small crabs, whilst the traps I used to estimate relative abundances were designed to census as many size-classes as possible. This means that in some parts of the fishery, effects of handling mortality on undersize crabs may be minimized. There is obvious potential for a more widespread adoption of such fishing gear.

In the light of the results discussed above (and those in Kennelly et al. 1990), new initiatives are attempting to assist this fishery. Firstly, a closure on the taking of Ranina ranina has been implemented during the spawning period to protect from handling mortality those ovigerous females susceptible to capture. Continued monitoring of commercial landings is assessing the effectiveness of this closure. Further, a new research project is attempting to develop and assess alternative baited traps which minimize the mortality of discarded conspecifics.

This study has shown that the use of a stratified, randomized baited trap survey, replicated throughout appropriate spatial and temporal scales, provided quantitative information on the relative abundances and distributions of various components of populations of Ranina ranina. These estimates were shown to be valuable in identifying potential problems in this fishery and in developing management strategies to solve them. Further, the use of such a survey means that it can be repeated easily at any future time and so be used to monitor fluctuations in the population after any changes in management - thus providing new information and, consequently, modified recommendations to management.
Acknowledgements. I sincerely thank J. Craig for his invaluable assistance at many stages of this research. D. Watkins and J. Hannan also provided excellent technical support. The field work would not have been possible without the vessels and expertises of J. Lavis and J. Spedding. Other technical support came from B. McKay, D. Kupa, P. Kennelly, C. Gray, P. Scanes, T. Walford, B. Garner and W. Piper Thanks are extended to Dr G. Chapman, C. Gray, D. Reid and R. West for critical reading the manuscript and to Dr $R$. Kearney for his ongoing support of the project. This work was funded by the Australian Fishing Industry Research Trust Account (Grant No. 86/63).

\section{LITERATURE CITED}

Barnard, K. H. (1950). Descriptive catalogue of South African decapod crustacea. Ann. S. Afr. Mus. 38: 396-399

Botton, M. L., Ropes, J. W. (1987). Populations of horseshoe crabs, Limulus polyphenus, on the Northwestern Atlantic continental shelf. Fish. Bull. U.S. 85: 805-812

Brown, I. W. (1986). Population biology of the spanner crab in south-east Queensland. Fishing Industry project 81/71 final report, Queensland Dept Primary Industries, Brisbane

Collie, J. S., Sissenwine, M. P. (1983). Estimating population size from relative abundance data measured with error. Can. J. Fish. Aquat. Sci. 40: 1871-1879

Conan, G. Y., Maynard, D. R. (1987). Estimates of snow crab (Chionoecetes opilio) abundance by underwater television - a method for population studies on benthic fisheries resources. J. appl. Ichthyol. 3: 158-165

Ehrhardt, N. M., Die, D. J., Restrepo, V. R. (1990). Abundance and impact of fishing on a stone crab (Menippe merceneria) population in Everglades National Park. Florida, Bull. mar. Sci. 46: 311-323

Fielding, A., Haley, S. R. (1976). Sex ratio, size at reproductive maturity and reproduction of the Hawaiian kona crab Ranina ranina (Linnaeus) (Brachyura, Gymnopleura, Raninidae). Pacif. Sci. 30: 131-145

Fletcher, W. J., Brown, I. W., Fielder, D. R. (1990). The use of standard and inverse Leslie experiments to estimate the abundance of the coconut crab (Birgus latro L.) in Vanuatu. Fish. Res. 9: 317--324

Jones, C. M., McConaugha, J. R., Geer, P. J., Prager, M. H. (1990). Estimates of spawning stock size of blue crab, Callinectes sapidus, in Chesapeake Bay, 1986-1987 Bull. mar. Sci. 46: 159-169

Kennelly, S. J. (1989). Effects of soak-time and spatial heterogeneity on sampling populations of spanner crabs Ranina ranina. Mar. Ecol. Prog. Ser. 55: 141-147

Kennelly, S. J., Craig, J. R. (1989). Effects of trap design, independence of traps and bait on sampling populations of spanner crabs Ranina ranina. Mar Ecol. Prog. Ser. 51: $49-56$

Kennelly, S. J., Watkins, D., Craig, J. R. (1990). Mortality of discarded spanner crabs Ranina ranina (Linnaeus) in a tangle-net fishery - laboratory and field experiments. J. exp. mar Biol. Ecol. 140: 39-48

Lipcius, R. N., Van Engel, W. A. (1990). Blue crab population dynamics in Chesapeake Bay: variation in abundance (York River, 1972-1988) and stock-recruit functions. Bull. mar Sci. 46: 180-194

Lockhart, F. D., Lindberg, W. J., Blake, N. J., Erdman, R. B, Perry, H. M., Waller, R. S. (1990). Distributional differences and population similarities for two deep-sea crabs (family Geryonidae) in the northeastern Gulf of Mexico. Can. J Fish. Aquat. Sci. $47 \cdot 2112-2122$ 
Melville-Smith, R. (1988). Comparative population size estimates for a portion of the red crab Geryon maritae stock off the south west African coast. S. Afr. J. mar. Sci. 6: 23-31

Miller, R. J. (1978a). Entry of Cancer productus to baited traps. J. Cons. int. Explor. Mer. 38: 220-225

Miller, R. J. (1978b). Saturation of crab traps: reduced entry and escapement. J. Cons. int. Explor. Mer. 38: 338-345

Miller, R. J. (1980). Design criteria for crab traps. J. Cons. int. Explor. Mer. 39: 140-147

Miller, R. J. (1983). Considerations for conducting field experiments with baited traps. Fisheries 8: 14-17

Miller, R. J. (1989). Catchability of American lobsters (Homarus americanus) and rock crab (Cancer irroratus) by traps. Can. J. Fish. Aquat. Sci. 46: 1652-1657

Miller, R. J. (1990). Effectiveness of crab and lobster traps. Can. J. Fish. Aquat. Sci. 47: 1228-1251

Onizuka, E. W. (1972). Management and development investigations of the kona crab, Ranina ranina (Linnaeus). Div. Fish Game Dept Land Nat. Res. Rep., Honolulu

Robertson, W. D. (1989). Factors affecting catches of the crab Scylla serrata (Forskal) (Decapoda: Portunidae) in baited traps: soak time, time of day and accessibility of the bait. Est. coast. Shelf Sci. 29: 161-170

Sinoda, M., Kobayasi, T (1969). Studies on the fishery of Zuwai crab in the Japan Sea. VI. Efficiency of the Toyama Kago (a kind of crab trap) in capturing the Beni-zuwai crab. Bull. Jap. Soc. scient. Fish. 35: 948-956

Sissenwine, M. P. (1984). The uncertain environment of fishery scientists and managers. Mar. Res. Econ. 1: 1-30

Sissenwine, M. P., Azarovitz, T., Suomala, J. B. (1983). Determination of fish abundance. In: Macdonald, A. G., Priede, I. G. (eds.) Experimental biology at sea. Academic Press, New York, p. 51-101

This article was presented by A.J. Underwood, Sydney, Australia
Skinner, D. G., Hill, B. J. (1986). Catch rate and emergence of male and female spanner crabs (Ranina ranina) in Australia. Mar. Biol. 91: 461-465

Skinner, D. G., Hill, B. J. (1987). Feeding and reproductive behaviour and their effect on catchability of the spanner crab Ranina ranina. Mar Biol. 94: 211-218

Tahil, A.S. (1983). Reproductive period and exploitation of the red frog crab, Ranina ranina (Linnaeus 1758) in Central Tawi-Tawi, Philippines. Philipp. Scient. 20: 57-72

Thomas, H. J. (1953). The efficiency of fishing methods employed in the capture of lobsters and crabs. J. Cons. perm int. Explor. Mer. 18: 333-350

Tunnicliffe, V., Jensen, R. G. (1987). Distribution and behaviour of the spider crab Macroregonia macrochira Sakai (Brachyura) around the hydrothermal vents of the northeast Pacific. Can. J. Zool. 65: 2443-2449

Wenner, A. M. (1972). Sex ratio as a function of size in marine crustacea. Am. Nat. 106: 321-350

Wenner, E. L., Barans, C. A. (1990). In situ estimates of density of golden crab, Chaceon fenneri, from habitats on the continental slope, southeastern U.S. Bull. mar. Sci. 46: 723-734

Wenner, E. L., Ulrich, G. F., Wise, J. B. (1987). Exploration for golden crab, Geryon fenneri, in the South Atlantic Bight: distribution, population structure, and gear assessment. Fish. Bull. U.S. 85: 547-560

Wenner, E. L., Wenner, C. A. (1988). Seasonal composition and abundance of decapod and stomatopod crustaceans from coastal habitats, southeastern United States. Fish. Bull. U.S. 87 : 155-176

Wigley, R. L., Theroux, R. B., Murray, H. E. (1975). Deep-sea red crab, Geryon quinquedens, survey off northeastern United States. Mar. Fish. Rev. 37: 1-27

Manuscript first received: November 24, 1991

Revised version accepted: July 13, 1992 